\title{
Sex-speare vs. Shake-speare?: On Nudity and Sexuality in Some Screen and Stage Versions of Shakespeare's Plays
}

\section{ABSTRACT}

The article attempts to address the issue of nudity and eroticism in stage and screen versions of Shakespeare's plays. Elizabethan theatrical conventions and moral and political censorship of the English Renaissance did not allow for an explicit presentation of naked bodies and sexual interactions on stage; rather, these were relegated to the verbal plane, hence the bawdy language Shakespeare employed on many occasions. Conventions play a significant role also in the present-day, post-1960s and post-sexual revolution era, whereby human sexuality in Western culture is not just alluded to, but discussed and presented in an open manner. Consequently, nudity on stage and screen in versions of Shakespeare's plays has become more marked and outspoken. Indeed, in both filmic and TV productions as well as stage performances directors and actors more and more willingly have exposed human body and sexuality to the viewer/spectator. My aim is to look at such instances from the perspective of realism and realistic conventions that the three media deploy and the effect nudity/sex can have on the recipient. The conclusion is that theatre is most conventional and stark realism and directness of the message need to be carefully dosed. Similarly to the theatre, television, more specifically television theatre, is, too, a most direct genre, as television is inherently a live medium, the broadcasts of which occur here and now, in the present tense (ideally). Film is markedly different from the two previous forms of art: it is narrated in the past tense, thus creating a distance between what is shown and the viewer, and allowing for more literalness. Naturally, particular cases discussed in the article go beyond these rather simple divisions.

\section{ABSTRACT}

3 During the recent $15^{\text {th }}$ Shakespeare Festival in Gdańsk, theatrical events as well as the reconstruction of the Fencing School Elizabethan theatre have been advertized as "Shakes in the city" ["Szeks w wielkim mieście”]. The title of my article is certainly indebted to this pun. 
The article is an attempt to address a rather controversial and debatable issue in Shakespearean criticism: the explicit presentation of sexually-informed (suggested) nudity. Shakespeare's plays abound in references to sexuality, both overt and covert. Eric Partridge's now classic book Shakespeare's Bawdy testifies to the critics' acknowledging that Shakespeare's morality did not meet the stereotypically Victorian standards. Even on the Elizabethan stage, subject to the strict political and moral censorship, verbal imaginings of nudity and sexuality, not only in the form of jokes, were paralleled to an extent by a visual representation of actors dressed in costumes imitating naked human skin. A faint echo of this practice can be found in present-day theatre when actors put on flesh-coloured apparel which stands for nakedness. Early film versions of Shakespeare's plays appear to perpetuate the Victorian approach to the touchy sexual innuendoes in the Bard's oewore: in Percy Stow's The Tempest (1908) Caliban, rather than attempting to rape Miranda, declares his love of her by placing the palms of his hands on his heart (it is quite curious why the director decided to include this scene in his rather short film, a scene that is only reported in the play). In Sven Gade and Heinz Schall's silent Hamlet (1921) with the then famous Danish actress Asta Nielsen in the role of the Prince even gender switching does not hinder a by-the-book treatment of love and sexuality (no explicit nudity allowed, of course), yet one of the final scenes presents unsuspecting Horatio placing his hand on the dead Hamlet's heart (i.e., breast) and discovering to his horror that Hamlet is a woman! Here, we deal with a fairly explicit sexual reference, actually shown on screen. In the post-sexual-revolution era the directors of Shakespeare's dramas have been granted greater freedom in the treatment of nudity and sexuality. Yet, there is allegedly a marked difference between representing sexuality on stage and on screen; furthermore, cinema and television do not treat sexual nudity, or nudity in general, in the same way. On top of it, one needs to consider the canonical, indeed, special status of Shakespeare in Western culture: on the one hand, the tradition of Bardolatry, on the other, approaching his works as litmus paper helping sound the contemporaneous problems. If it so happens that among them is human sexuality, so be it.

As a result, I would like to address the issues of realism and convention on screen and stage, the (ab/mis) use of sexuality in screen and stage versions of Shakespeare's plays, as well as crossing and/or maintaining the borders of filmic/televisual/theatrical provocation by exposing the viewers/spectators to scenes of nudity and/or explicit sexuality. I will 
exemplify this discussion with a selection of screen and stage productions of Shakespeare's plays containing post-1960s treatment of sex and nudity. As one may expect, it would be rather difficult to cover the rich variety of both stage and screen productions and thus offer any conclusive inferences. One should be especially cautious in view of the frequent practice of blending media on both stage and screen whereby conventions become blurred, which opens room for a more or less explicit presentation of sexuality. Therefore, I have excluded from the discussion productions in which such blends prevail, focusing on examples which allow for a more unequivocal generic/media allocation, which-consequently-helps establish the kind of realistic conventions deployed in them.

I would like to begin the discussion of Shakespeare and nudity and sexuality with a brief overview of the concepts of realism and conventions and their applicability to stage performances, TV theatre productions and films. There are many definitions and understandings of the concept of realism in art in general and in literature in particular. A rather tentative and general idea concerning the use of realism in art has been proposed by Corner and Ang: "empirical realism" (likeness of setting, social action and ostensible theme) and "formal realism" (formal conventions). Ang also lists one more form of realism: "emotional realism" which he defines as "deep-level resonances with the emotional organization of the viewer," helping to "link the text and experience in a way which fits the data" (Ang 44; qtd. in Corner 101). Ang's concept becomes a useful tool in the present discussion in which I will often need to refer to the recipient's emotional response to the production, or his/her acceptance or rejection of the deployed realism convention and its generic/medial suitability. ${ }^{1}$

Film and television are not equally realistic; paradoxically, it is film that is less realistic than television in that the ideal function of the latter is to show in a live coverage what happens in front of the camera lens, without any other intervention or preparation for the shooting. Now, behind such an approach there lies an assumption that TV material does not undergo any editing (which is not true, of course) and is always broadcast live, happens in the now, the present (which is only partially true). Furthermore, even if a broadcast is aired live, it is transmitted by a number of cameras, as is the case with sports events, and the director of the show decides which perspective will be presented on screen. So, in fact, the broadcast is edited although—unlike the cinema-the editing occurs in front of our eyes.

1 I am aware of the fact that any debate about reception should call for at least a survey of the spectators'/viewers' opinions. Yet, a critic is also a recipient of a production who should moreover be conscious of his/her prejudices and limitations. It is from this position, occasionally assisted by reviews, that I will interpret the productions discussed in this article. 
Nevertheless, such editing is markedly different from a filmic montage. In other words, we could treat television as a live report of certain events. It is its convention (formal realism) and perhaps a more profound form of empirical realism than film (again, in its ideal form). If we borrow Ang's concept of "emotional realism" and modify it, we could then say that television brings about a sense of directness, so well illustrated by the metaphor of television as a window which overlooks the real world surrounding us. This sense of directness is even present in those telegenic forms which lie halfway between stage and cinema, such as television theatre, even in its latest, rather cinematic form (with the more extensive use of cutting and montage and the productions being first filmed/recorded and shown at a later date). When comparing film and television theatre, Limon remarks, "With the television's theatre's 'artificiality' and conventionality it [paradoxically] becomes as if more real, since it produces an illusion of the now (and, in this way, an illusion of voyeurism)" (96). Consequently, the presentation of nudity on television is more real (or: realistic) than on the big screen; the basic reason for it is that the viewer is constantly aware of the double status of the fictitious figure: that of the character and that of the actor/actress playing the character in the quasi-theatrical performance that is relayed by television (which thus makes it doubly fictitious, without, however, enlarging the distance!). The enhanced sense of the presence of the actor results from the directness of the medium. ${ }^{2}$

On stage the situation is quite similar: the spectator directly faces a figure and the actor/actress playing them (the empirical persons). As a result, one more aspect of the television art must be considered here, too: the distance between the viewer and the set. It is rather close; the contact is termed by TV theoreticians as intimate, which of course is concordant with the idea of the directness of the viewer's exposure to the performance. Accordingly, explicit nudity on television should be viewed as rather unwelcome, as it may be a source of discomfort for the viewer since they do not conform to his/her horizon of expectations and sense of emotional realism. The viewer finds him/herself in the position of a voyeur secretly watching from a close distance what is considered in Western culture a most intimate and private aspect of human life (of course, the situation is even more difficult when a sexual activity is shown).

Television theatre is a very specific medium also in that its convention leaves room for such an unrealistic and artificial element as verse dialogues that "pretend" to reflect everyday communication, which is also true about the theatrical stage. The symbolism of the stage and television

2 Conversely, on film the distance is greater and the recipient is focused more on figures impersonated by actors than actors themselves. 
set (no matter whether studio-, location- or stage-based) runs rather counter to an explicit and realistic presentation of violence, nudity or sex (or the three of them). A good example illustrating this thesis can be the scene of Lavinia's rape in Monika Pęcikiewicz's production of Titus Andronicus (2006) from the Gdańsk Teatr Wybrzeże, in which music and symbolic movement of the actors, not even faintly reminiscent of the overt brutality of rape, conveys a message shocking enough for the audience. Lavinia is dragged up a ladder by Demetrius and Chiron to a dark opening above the stage, where they finally, after a great deal of physical effort, disappear. In this case, the reliance on Shakespeare's language and a unique manner of showing both physical and psychological pain caused by the rape and mutilation contribute to the effect of emotional realism expected and accepted by the audience.

Alternatively, the presentation of Desdemona getting ready for bed before she is strangled by her husband in the 1981 Othello directed by Andrzej Chrzanowski is more explicit-Joanna Pacuła is stripped naked by Emilia before she puts on her nightgown behind a semitransparent veil. In the case of this particular production, due to a financial crisis sweeping across Polish television, the set was exceptionally bare (which, incidentally, was quite concordant with the television theatre aesthetics) and in the scene in question it is partitioned by loosely hanging veils delineating the space of Othello and Desdemona's bedroom. It should be emphasized, however, that Desdemona's nudity is only to a degree marked sexually (hers and Othello's marriage is to be finally consummated) and the image of the naked woman is blurred by the veil, which makes it less explicit.

This is not the only instance when nudity appears in Polish telegenic productions of Shakespeare's plays. Two other teleplays, both original television theatre productions rather than filmed stage performances, were shot on location: Łukasz Barczyk's Hamlet (2004) set in the milieu of the old Wieliczka salt-mine and Jan Englert's Julius Caesar (2005) set in, among others, the main library of the University of Warsaw. The setting matters here as the teleplays clearly move away from the television studio into location, which apparently may facilitate a departure from the conventions prevalent so far. Now, the fact that Barczyk decided to shoot his Hamlet in the shafts and pits of an old salt mine does not affect much the rather traditional poetics of television theatre and the conventions it relies upon as well as the sense of directness, signalled above. For these reasons, Kamila Baar's Ophelia appearing stark naked in the scene of her madness seems definitely strange and out of place. This has been noted by critics, too: Olga Katafiasz cannot find any explanation for exposing the character's nudity (112). If it were meant to signify Ophelia's madness and vulnerability, then the sign is rather crude and unconvincing. One could recall 
here the Elizabethan practice whereby madness was marked by dishevelled hair and a nightgown, not nudity; indeed, a naked body in television theatre is too literal, it affects the sense of emotional realism and produces the effect of voyeurism, due to the illusion of directness and intimacy caused by the medium. This particular scene in Shakespeare's text is loaded with sexual innuendoes; an explicit presentation of the naked body of a young woman is quite superfluous on stage or television set. ${ }^{3}$ At the same time, the idea of sexuality is presented in the production in other, less ostensible ways: before his departure for France, Laertes enjoys the company of prostitutes, while one of the Players is a drag queen. These aspects of sexuality, however, are only signalled, perhaps suggesting the moral corruption of Denmark, a sense of decadence, whereas Ophelia's madness is rendered in a manner which the viewer may find difficult to accept, mainly because the medium (television theatre) prefers synecdoche and symbolism over literalness, which is true in more general terms about any stage.

Before we proceed any further, a remark is due: madness in Shakespeare's plays put on screen and stage has been marked by nudity: I would like to mention here, for example, Peter Brook's King Lear, in which Edgar when assuming the identity of Tom O'Bedlam, doffs his clothes and covers his naked body with mud. Likewise, in Lev Dodin's stage version of the same play, Lear's party, after the king goes mad, walks on stage stark naked (men only), which may function as a token of a world where traditional values are turned upside down and the characters search for new identities. ${ }^{4}$ In a Spanish stage production of Hamlet directed by Jarosław Bielski (Réplika Teatro) ${ }^{5}$ Ophelia's death is shown by the actress walking across the stage naked with a long veil on her body which, when she is about to leave the stage, slips off her body to the ground. Although both Brook and Dodin employ different media, Brook's film lacks the lavish use of many elaborate settings and comes close to what one may associate with both television art and, naturally, his theatrical experience. In other words, in both productions nudity appears as a special sign which draws attention to itself. Thanks to low-key lighting it is not exposed so obviously as in Barczyk's teleplay and thus makes the viewer/spectator shift their attention to what it could possibly signify. In the case of Bielski's small-scale performance, paradoxically, nudity is subjected to the symbolic convention that

3 In the production of Hamlet directed by Jan Englert and shown on Polish television in 1985 (shot in a studio with filmic added scenes) Ophelia (Ewa Domańska) is dressed in a soiled nightgown; however, when she offers rue to Gertrude she thrusts it onto the latter's bosom and crotch, thus marking female sexuality. In this case, we deal with a sign rather than an explicit representation.

4 The performance was presented at the $11^{\text {th }}$ Shakespeare Festival in Gdańsk in 2007.

5 Shown at the $12^{\text {th }}$ Shakespeare Festival in Gdańsk in 2008. 
the theatre deploys: the dying Ophelia, or to be more precise, her "dead" body, is clothed in a shroud, which subsequently functions as the figure's earthly remnants. The body (of the actress) that substantiated Ophelia is gone and what is left is only the veil/shroud on the ground, a metonymy of the character's corpse.

The above discussion shows that the concept of madness can be illustrated by mad characters in the nude. It seems that it works for King Lear, less so for Hamlet (should the Prince go naked, too?). ${ }^{6}$ Interestingly enough, in her version of Hamlet, Monika Pęcikiewicz also had her Ophelia strip half-naked; however, under different circumstances: she appears such to Hamlet in the nunnery scene. The idea is that Polonius uses his daughter as a bait to elicit from Hamlet the reasons for his strange conduct. Pęcikiewicz's Polonius, dressed like a Catholic priest, prostitutes Ophelia to achieve his ends ${ }^{7}$; he makes her take off her bra and then pushes her towards Hamlet. In turn, in the scene of madness Ophelia wears a long, white gown (quite Elizabethan in nature) and kills herself with a dagger; that is, she attempts to do so: the gown is soaked with what looks like blood; a huge puddle is soon formed on the stage. Ophelia does not die, though; instead, she takes off her gown only to reveal underneath plastic bags that contained the blood-looking liquid. This scene is a good illustration of the director's (and actors') distance to both the play and the characters, a sort of metatheatrical comment on how to transform an Elizabethan play into present-day popular culture. Due to this distance, which is characteristic of the whole of the performance, Pęcikiewicz keeps at bay the viewer's possible emotional response, which thus becomes more detached, while nudity appears to be less controversial.

Such a distance is necessary in a theatre which relies on convention and symbolism; in the case of this production, Pęcikiewicz appears to experiment with convention and "empirical realism" as well as "emotional realism." But this experiment does not cross the bounds of the kind of realism called for on the stage: by providing the parenthesis of distancing devices the director was given some room to introduce a more direct representation which is treated by the recipient as yet another sign and not a literal demonstration. Consequently, it does not violate the theatrical conventions. Furthermore, Ophelia's nudity is justified in the production because the character after the encounter with Hamlet hurriedly picks up

6 As it was actually the case in Nicolai Kolyada's and Radosław Rychcik's Hamlets shown at the $15^{\text {th }}$ Shakespeare Festival in Gdańsk in 2011; in both cases, however, it is difficult to explain the figures' nudity by means of real or pretended madness.

7 It is congruent with Hamlet's equivocal address to Ophelia's father: "You are a fishmonger," which may suggest that Polonius prostitutes his daughter. 
articles of clothing to cover her bare breasts and leaves the stage, thus clearly ashamed of the humiliation caused by Polonius.

Perhaps a similar idea underlay the overall concept of the television version of Julius Caesar (2005) directed by Jan Englert, already mentioned above. On the one hand, Englert draws on the poetics of television theatre in stressing the verbal plane and the dialogues and using synecdoche, as in the scene of Caesar's murder in which senators wear over their modern suits long scarves draped to resemble Roman togas. Likewise, the vast spaces of the Library of the University of Warsaw function as the Forum Romanum. This symbolism is intertwined with a more literal realism: the interior of a television studio (for the sake of a political debate), a shopping mall, a pub, etc. where Roman/Polish citizens spend their time. One such location is Caesar's villa, with a small swimming pool, a token of Caesar's status, on the one hand, and Roman-ness, on the other. It is in this swimming pool that Caesar takes a swim, ${ }^{8}$ surrounded by the senators, before he sets out for the Senate, where he will be murdered. In the Roman fashion, the actor is stark naked; he quickly slips into the pool so the nudity is not much exposed, yet it is quite palpable and realistic. The special nature of the scene is the fact that the senators are there all along and wait patiently for Caesar to finish swimming. The scene, thus, by employing nudity in a specific context, is another extension of Roman-ness, perhaps a kind of cliché, yet one which effectively conveys this notion to the viewer. The idea of Roman-ness provides a distancing device whereby the nudity can be acceptable to the viewer and may be concordant with the spirit of Shakespeare's original. At the same time, it needs to be stressed that nudity in this particular production is not associated with sexuality; rather it points at a different approach to naked human body in ancient Roman times (thus informing the illusion of Roman-ness).

These examples clearly suggest that stage theatrical and television theatrical conventions rely to a degree on symbolism, or, shall we say, formal realism, whereby the artist and the recipients of their work agree on certain forms of artistic expression which are meant to stand for reality. Such conventions do not call for literalness, in spite of the fact that both types of theatre belong to performing arts which show rather than tell (which of course can also be contested when one recalls the significance of the verbal plane in drama, especially Shakespearean drama, as well as the narrative element provided by the camera in television theatre).

8 Which reminds one of the executive swim the CEO of the Denmark Corporation (Kyle McLachlan) had in Michael Almereyda's Hamlet (2000) in the presence of both Gertrude and Polonius. 
Before proceeding to film proper, I would like to discuss yet one instance from stage theatre-Monika Pęcikiewicz's (again) A Midsummer Night's Dream. Some critics hailed it as "post-sexual" ("Postseksualny i postuczuciowy")"; Aneta Kyziol in her review called it "a gymnastic erotic layout"; one could enumerate more such responses to the performance. All of them appear justified: what is almost a handbook version of a romantic comedy is entirely deprived of its romantic appeal. ${ }^{10}$ Instead, we have a film set, allegedly providing a distancing device, and an introduction, which in fact turns out to be a film. ${ }^{11}$ In the film the spectator/viewer witnesses the process of casting for the roles in the play, in which candidates are exposed to rather extreme ends: they are coupled and told to undress as well as express their sexuality. A film is set in the past; it uses the past tense, which - in the theatre-is particularly important. Such a device allegedly provides a most powerful distancing device. Yet, a spectator does not go to the theatre to watch characters in films but live actors on stage. When the former is translated into the latter, we are in trouble: Pęcikiewicz does her best to make the viewer believe that they are not in the theatre, yet she fails. Since the principle is "rape whatever can be raped," physical violence, this time without nudity, yields to something one would associate with the screen, not the stage. Nevertheless, the spectator is watching a stage performance, not a film; the effect, thus, is rather discomforting.

Nudity does appear in another production, presented at the $14^{\text {th }}$ Shakespeare Festival in Gdańsk in 2010. When Viola in Twelfth Night directed by Michał Borczuch (the Jan Kochanowski Theatre from Opole) crossdresses to protect herself in Illyria, she actually exchanges clothing with one of the sailors-they both strip naked and she puts on his attire. One could question the necessity for such a solution in a performance in which symbolic representation is very often employed. However, the director used a kind of distancing device for this particular scene: since the acting area includes part of the auditorium, he has the actors occupy the most distant rows of seats, distant from the spectators' perspective. A possible explanation for introducing nudity into this performance could be an attempt to highlight Viola's vulnerability, the fact that she, a young, lonely girl, is truly exposed to a most serious danger in Illyria. The change of clothing is both asexual and sexual, in that the figure undresses only to put on men's apparel, which in turn is to protect her against rape, a motif that haunts Shakespearean

9 No indication of the author in the electronic sources I have consulted: see bibliography.

10 Which may be a result of a problem a present-day reader of Shakespeare may have with the very serious threats Egeus issues with reference to his daughter, Hermia, or the confusions which the Athenian lovers partake in (I will return to this problem later on).

11 Pęcikiewicz quite willingly resorts to multimedia performances; cf. her Hamlet. 
crossdressing but is never fully articulated. Paradoxically, then, the actress's nudity (Aleksandra Cwen) becomes a token of the violation of the character's intimacy in order to avoid a more grievous intrusion into it.

Furthermore, this scene (and another, in which Viola appears half naked) serves a most concrete purpose: to make the spectator realize that Shakespearean romantic comedy is quite different from its Hollywood counterpart, and to rid the performance of the fairy-tale-like atmosphere that is sometimes generated in stage or screen productions (cf. Nunn's film).

It seems that no justifications for the introduction of more explicit nudity and/or sexuality are needed when it comes to film, which-like a photograph-records what is past and narrates in the past tense, just like the novel (the same is true about a television film, see ShakespeaRetold ${ }^{12}$ ). As a result, the distance between the viewer and the film is by definition, as it were, quite safe. Yet, critics even in the post-sexual-revolution era find it difficult to deal with overt sexuality and nudity; the late Kenneth Rothwell in his seminal $A$ History of Shakespeare on Screen quotes a reviewer who referred to Celestino Coronado's A Midsummer Night's Dream (1985) “as having 'plenty of uninhibited nudity' and 'a fairy king and queen [who] are splendidly campy characters'” (194). Nudity-that of the fairies as well as of the Athenian lovers-is not the only element that characterizes this anti-Hollywood and anti-establishment voice in the cinema of the 1980s. Coronado and Lindsay Kemp (who plays the part of Puck) cast the blind Incredible Orlando as Titania (drawing on the actor's homosexual reputation) and have Lysander and Hermia actually make love in the Athenian wood. They go even further: after Puck's intervention, the naked Lysander successfully chases Demetrius (because he saw Demetrius first after waking up), while Hermia makes love to Helena! The camp and sexually loaded atmosphere of the film is, however, framed in the milieu of ballet and operatic conventions: Titania and Oberon virtually sing arias, and there are many ballet sequences, especially in the scenes with the fairies. These conventions shed a strange light on the use of nudity and sexuality; being highly symbolic (opera), the conventions may appear to run counter to the literal presentation of the naked bodies. However, the language of ballet is not human voice but human body whose shape and form is only underlined by the tight ballet attire. As a result, it seems only natural that naked human body be fully exposed, which runs counter to traditional opera relying so heavily on signs rather than literalness. The introduction

12 ShakespeaRetold is a BBC miniseries produced in 2005 and comprized of four films based on A Midsummer Night's Dream, Macbeth, Much Ado About Nothing and The Taming of the Shrew. The idea of the series was that Shakespeare's plays were modernized and their action set in modern Britain. For the purpose of the present discussion, ShakespeaRetold is an example of television films rather than teleplays. 
of the elements of opera and ballet, both defying, as it were, typical filmic realism, renders the atmosphere of the movie eerie and unrealistic, most suitable for the feats of magic which the play abounds in. Consequently, nudity and sexuality can be more explicitly shown in Coronado's film, not only thanks to the realism the medium deploys but the distancing devices it uses as well.

Interestingly enough, another camp-movie that Coronado's film certainly looks back and is indebted to, Derek Jarman's (in)famous The Tempest (1979), also resorts to certain conventions, shall we say, musical ones. As Kenneth Rothwell reminds us, "several dozen men in white sailor suits along with [Elisabeth] Welch [a black blues singer] as soloist do a ragged song-and-dance routine of 'Stormy Weather'” (197). This scene concludes the film, but expresses quite well a most eerie and oneiric atmosphere that pervades the movie. It is in such atmosphere that the viewer sees Caliban (the Incredible Orlando, or Jack Birckett, again) watch halfnaked Miranda washing. When she spots him, they exchange meaningful glances and laugh. The musical conventions function as a distancing device, preventing the viewer from assuming the state of "willing suspension of disbelief" and thus making them treat the events shown on screen as unreal, whereas any scenes containing at least a hint of sexuality, scenes of nudity, are relieved of such potential thanks to such distancing devices, often leading to comic effects. The scene discussed above certainly can be considered comic; to a degree, the spectacular image of naked Caliban sucking on naked Sycorax's breast (Sycorax is stylized here like the Venus of Willendorf) is comedic, also in that it can be treated as a parody of motherhood.

The most explicit and conspicuous example of nudity shows, however, Ferdinand, walking out of the sea, cold and wet, who-when he reaches Prospero's mansion-curls up shivering on the floor. Let me emphasize the fact that this scene, and the ones presented above, are further framed in the specific atmosphere (after all, at the very beginning of the film we learn that it is conceived of as a projection of Prospero's dream), ${ }^{13}$ which, too, distances the viewer from what is shown; as a result, the presentation of nudity appears to be by all means acceptable. Prospero's dream is marked in the film by the specific low-key lighting, use of chiaroscuro and the aesthetics of ugliness and decay. The latter aspect of the film's aesthetics is another element ensuring the viewer's distance to nudity and sexuality: since Jarman contested the mainstream culture, including Hollywood cinema, he explicitly deprives his characters of the traditional

13 A similar device is used by Coronado in his A Midsummer Night's Dream-it is Puck who dreams what we see on screen. 
sexual appeal. Ferdinand's body is additionally desexualized by the use of the blue filter whereby the shots on location, which constitute a sort of a dream-within-a-dream, are monochromatic and evoke an illusion of cold and gloominess, leaving hardly any space for sexuality.

Certainly this is not true about Kenneth Branagh's epic Hamlet, in which, "Alas, poor Ophelia," one might like to paraphrase the Prince's exclamation, Kate Winslet is shown making love to Branagh's Hamlet in one of the numerous flashbacks (the director does not use nudity to indicate madness). Although Branagh transposes the action of the play to the nineteenth century (which may remind the recipient of Victorian morality), he produces a film for the sake of the late-twentieth-century viewer, who, as a result of the director's decision, has no doubts about the nature of Hamlet and Ophelia's relationship. However, since the film was meant to be screened to the widest possible audience, nudity is rather suggested than explicitly presented, in a Hollywood style and practically limited to flashbacks, a filmic convention which defies empirical realism, constituting a film-within-a-film sequence. ${ }^{14}$

Nudity and sexuality are also deployed by Oliver Parker in his Othello, in which the Moor of Venice is haunted by flashbacks of his wife's allegedly having sex with Cassio. In order to emphasize the effectiveness of Iago's scheming and the state of Othello's mind the scene that the Moor imagines must, too, be visualized for the viewer realistically. Where Branagh used flashbacks to inform the viewer about the "state of affairs," Parker exploits them in a different way: to mark off the filmic reality from Othello's imaginings of what never occurred between Cassio and Desdemona. Both ways of employing flashbacks, however, are filmic devices showing the working of a character's mind (memories and imagination), ${ }^{15}$ providing the viewer, too, with a distance to presented events.

One could say that Franco Zeffirelli was in this respect less conservative, as he did not hesitate to show the teenage Olivia Hussey's breasts or Leonard Whiting's buttocks in his highly realistic version of Romeo

14 Branagh's film abounds in flashbacks and flash-cuts, which Bernice Kliman referred to as "flashcut excess." The flashbacks and flash-cuts are, however, quite congruent with the epic dimension of the film and do provide a distancing device for the viewer.

15 There is a fundamental difference between the presentation of memories in Branagh's film and Othello's imaginings in Parker's movie, which affect the kind of distance produced by the flashbacks. In the former, the viewer sees both Hamlet and Ophelia making love, although it is suggested that these memories are recalled by one character only, so a more realistic shot would include a limited perspective and a hand-held camera, for example. Consequently, the viewer's distance to the presentation of sexuality is enhanced. In the latter, Othello may imagine both characters making love as his perspective is that of an observer, not participant, a kind of voyeur. However, the viewer is aware of the fact that this does not belong to the film's reality. 
and Juliet (1968). Zeffirelli did that, however, in the height of the sexual revolution, which ushered in greater freedom in the manner sexuality was presented in Western culture, including film. The director drew on the revolution in two ways: one, he presented two very young characters rebelling against the establishment and, two, implementing this rebellion in the realm of love, also physical love, which-in the case of the film-needed to run counter to the thitherto prevailing Hollywood norms. Another reason for introducing nudity and sexuality in the film is Zeffirelli's reputation as an utter realist; consequently, one is not surprised to find not only teenagers cast in the eponymous roles but overt sexuality of the young lovers as well. The presentation of nudity and sexuality in the film is thus justified, too, by the overall poetics of the director's style.

Zeffirelli sought realism in his film productions also in that he paid attention to historical details, which he combined with, shall we say, modern morality and latest film trends. ${ }^{16}$ Realism is what Michael Radford attempted to achieve in his The Merchant of Venice (2005). Unlike Zeffirelli's, however, Radford's style appears utterly conservative, in the vein of most traditional Hollywood industry, combined with a care for political correctness. ${ }^{17}$ In his search of a convincingly realistic image of Venice, the director, having researched the historical material, introduces prostitutes onto Venetian streets, who-as a sign of their profession-walk bare-breasted. These characters are introduced into the movie not only to symbolize the moral corruption of Venice and to satisfy the director's desire for historical accuracy, but also to highlight Shylock's plight: when he walks around the city desperately looking for Jessica, it is only the prostitutes who feel pity for the distraught father (as opposed to the well-off Venetian citizens, their clients). Here, the sexuality of the prostitutes is toned down by, on the one hand, the historical facts that the director refers to and, on the other, the tearful and simplistic presentation of Shylock's misfortune.

Film is a very realistic medium, therefore nudity and sexuality are often presented in an explicit manner. Interestingly enough, it is a convention that a viewer has long got used to. Today, one accepts the actor's or actress's naked body on screen as a natural and obvious element of the film and expression of, among others, human sexuality. The changes in

16 This is visible, too, in his version of Hamlet (1990), in which he recreated a medieval castle, set action in the austere scenery of the North of Europe and cast an action-movie actor, Mel Gibson, as the Prince.

17 This was perhaps Radford's way of dealing with a difficult play in the postHolocaust era; according to Małgorzata Sugiera, "two plays by Shakespeare are in particular controversial now, calling for ideological corrections ... The Taming of the Shrew and ... the anti-Semitic Merchant of Venice" (7, my translation). For more, see Fabiszak ("Are We Being Politically Correct Yet"). 
the Western approach to sexuality following the sexual revolution of the 1960s as well as the distance that the camera provides and the nature of film as a narrative in the past tense contribute to our acceptance of scenes of overt nudity and sex. It is less obvious, as I hope it transpires from the discussion above, in the case of stage or television theatre, which rely to a greater degree on artifice and symbolism; but for anybody who has been following the development of the Polish theatre, for example, it has become obvious that nudity is employed more and more often to a better or worse effect. When combined with Shakespeare's classic drama, one is not surprised that the Bard goes bawdy; after all, his plays must be updated in performances and screen productions, made topical to help directors address present-day issues. Let us note that such changes are not only characteristic of how Shakespeare's plays are shown on stage or screen but also how the texts of the plays have been altered or translated into other languages, in the case of productions in languages other than English. When it comes to Polish, translations have been most of the time quite Victorian in nature, with the exception of Maciej Słomczyński's and Stanisław Barańczak's ones, although only to a degree. My guess is that the degree results from Victorian-like morals, on the one hand, and, on the other, the genuine meaning of the terms in Early Modern English, a meaning that cannot be completely determined.

\section{WORKS CITED}

Ang, Ien. Watching Dallas. Soap Opera and the Melodramatic Imagination. London: Methuen, 1985. Print.

Corner, John. "Presumption as Theory: 'Realism' in Television Studies." Screen 33.1 (1992): 97-102. Print.

Fabiszak, Jacek. "Are We Being Politically Correct Yet? The Fortunes of Michael Radford's 2004 The Merchant of Venice and Shakespearean Text." Kwartalnik Neofilologiczny LII.4 (2005): 288-300. Print.

Hamlet. Dir. Michael Almereyda. Perf. Ethan Hawke, Kyle MacLachlan, Diane Venora, Bill Murray, Julia Styles. Double A Films, 2000. Film.

Hamlet. Dir. Łukasz Barczyk. Perf. Michał Czernecki, Janusz Gajos, Grażyna Szapołowska, Kamilla Baar, Jan Frycz. TVP, 2004. Teleplay.

Hamlet. Dir. Jarosław Bielski. Perf. Raúl Chacón, Borja Manero, Socorro Anadón, Marta Eguía. Réplika Teatro, Madrid. 2007 (shown at the 12 $2^{\text {th }}$ Shakespeare Festival in Gdańsk in 2008). Stage performance.

Hamlet. Dir. Kenneth Branagh. Perf. Kenneth Branagh, Julie Christie, Derek Jacobi, Richard Briers. Castle Rock Entertainment, 1996. Film.

Hamlet. Dir. Jan Englert. Perf. Jan Frycz, Ewa Domańska, Ewa Dałkowska, Tadeusz Huk, Mirosław Konarowski, Piotr Machalica. TVP, 1985. Teleplay. 
Hamlet. Dir. Sven Gade and Heinz Schall. Perf. Asta Nielsen, Mathilde Brandt, Eduard von Winterstein. Art-Film GmbH, 1921. Film.

Hamlet [Gamlet]. Dir. Nicolai Kolyada. Perf. Oleg Yagodin, Viera Tswitkis, Yevgeny Chistyakov, Sergei Fyodorov. The Kolyada Theatre, Yekaterinburg. 2007 (shown at the $15^{\text {th }}$ Shakespeare Festival in Gdańsk in 2011). Stage performance.

Hamlet. Dir. Monika Pęcikiewicz. Perf. Michał Majnicz, Mariusz Zaniewski, Ewa Skibińska, Anna Ilczuk. Teatr Polski, Wrocław. 2008 (shown at the $12^{\text {th }}$ Shakespeare Festival in Gdańsk in 2008). Stage performance. Hamlet. Dir. Radosław Rychcik. Perf. Tomasz Nosiński, Mirosław Bieliński, Karolina Porcari. The Stefan Żeromski Theatre, Kielce. 2011 (shown at the $15^{\text {th }}$ Shakespeare Festival in Gdańsk in 2011). Stage performance. Julius Caesar [Juliusz Cezar]. Dir. Jan Englert. Perf. Jan Englert, Jan Frycz, Jerzy Radziwiłłowicz. TVP, 2005. Teleplay.

Katafiasz, Olga. “Trailer.” Didaskalia 59/60 (2004): 111-12. Print.

King Lear. Dir. Peter Brook. Perf. Paul Scofield, Irene Worth, Susan Engel, Anne-Lise Gabold. Athéna Films, Filmways Pictures, 1971. Film.

King Lear [Korol Lir]. Dir. Lev Dodin. Perf. Petr Semak, Elizaveta Bojarskaya, Daria Rumyantseva, Danila Kozlovsky. The Maly Drama Theatre-Theatre de l'Europe, St Petersburg. 2006 (shown at the 11 $1^{\text {th }}$ Shakespeare Festival in Gdańsk in 2007). Stage performance.

Kliman, Bernice. "The Unkindest Cuts: Flashcut Excess in Kenneth Branagh's Hamlet." Talking Shakespeare: Shakespeare into the Millenium. Ed. Deborah Cartmell and Micheal Scott. Houndmills: Palgrave, 2001. 151-67. Print.

Kyzioł, Aneta. "Gimnastyczny układ erotyczny." Rev. of Sen nocy letniej [A Midsummer Night's Dream], dir. Monika Pęcikiewicz. Polityka. Polityka, 8 Apr. 2010. Web. 18 Oct. 2011.

The Merchant of Venice. Dir. Michael Radford. Perf. Al Pacino, Jeremy Irons, Joseph Fiennes, Lynn Collins, Zuleikha Robinson. MGM, 2005. Film.

A Midsummer Night's Dream. Dir. Celestino Coronado. Perf. Lindsay Kemp, Manuel Varga, Jack Birkett, Annie Huckle, Attilio Lopez. Cabochon. Televisión Española, 1985. Film.

A Midsummer Night's Dream [Sen nocy letniej]. Dir. Monika Pęcikiewicz.

Perf. Michał Chorosiński, Marcin Czarnik, Mirosław Haniszewski, Anna Ilczuk, Adam Cywka, Marcin Pempuś. Teatr Polski, Wrocław. 2010 (shown at the $14^{\text {th }}$ Shakespeare Festival in Gdańsk in 2010). Stage performance.

Limon, Jerzy. Trzy teatry [Three Theatres]. Gdańsk: słowo/obraz terytoria, 2004. Print.

Othello [Otello]. Dir. Andrzej Chrzanowski. Perf. Daniel Olbrychski, Piotr Fronczewski, Joanna Pacuła. TVP, 1981. Teleplay. 
Othello. Dir. Oliver Parker. Perf. Laurence Fishburne, Kenneth Branagh, Irène Jacob. Castle Rock Entertainment, 1995. Film.

Partridge, Eric. Shakespeare's Bawdy. London: Routledge, 1968 [1947]. Print.

"Postseksualny i postuczuciowy Sen nocy letniej" ["Post-sexual and Postemotional A Midsummer Night's Dream"]. Dlastudenta, dlastudenta. pl, 16 Mar. 2010. Web. 18 Oct. 2012.

Romeo and Juliet. Dir. Franco Zeffirelli. Perf. Leonard Whiting, Olivia Hussey, John McEnery, Michael York. BHE Films, Verona Produzione, 1968. Film.

Rothwell, Kenneth S. A History of Shakespeare on Screen. A Century of Film and Television. Cambridge: Cambridge UP, 2004. Print.

Sugiera, Małgorzata. Wariacje Szekspirowskie w powojennym dramacie enropejskim [Shakespearean Variations in Postwar European Drama]. Kraków: Universitas, 1997. Print.

The Tempest. Dir. Derek Jarman. Perf. Heathcote Williams, Toyah Willcox, Jack Birkett. Boyd's Company, 1979. Film.

The Tempest. Dir. Percy Stow. Clarendon, 1908. Film.

Titus Andronicus [Tytus Andronikus]. Dir. Monika Pęcikiewicz. Perf. Mirosław Bako, Dorota Kolak, Karolina Adamczyk, Piotr Jankowski. Teatr Wybrzeże, Gdańsk, 2006. Stage performance.

Trwelfth Night [Wieczór trzech króli]. Dir. Michał Borczuch. Perf. Aleksandra Cwen, Beata Wnęk-Malec, Mirosław Bednarek, Jacek Dzisiewicz. The Jan Kochanowski Theatre, Opole, 2010 (shown at the $14^{\text {th }}$ Shakespeare Festival in Gdańsk in 2010). Stage performance.

Twelfth Night. Dir. Trevor Nunn. Perf. Imogen Stubbs, Steven Mackintosh, Ben Kingsley, Helena Bonham-Carter, Nigel Hawthorne. BBC Films, Circus Films, 1996. Film. 